\section{Growth of US defence spending squeezes space science plans}

\section{Washington}

LAST week, exactly a year after the space shuttle Challenger exploded in flight, the new US presidential science adviser, Dr William Graham, briefed a committee of the House of Representatives on the administration's plans for science, space, and technology. And once again, military objectives, not science policy, dominated the picture.

The statement from Graham, weapons expert and former acting administrator of the National Aeronautics and Space Administration (NASA), echoed the rhetoric of the Reagan administration on using science and technology to strengthen economic competitiveness while maintaining national security. He cited the 13 per cent increase in the 1988 budget for research and development and a 17 per cent increase for basic research funding through the National Science Foundation (NSF) as proof of the president's commitment to a national scientific enterprise. But when committee members probed him on specifics, Graham revealed imbalances between this administration's civilian and military science policy and his own unfamiliarity with issues outside space and defence.

The budget for 1988 includes $\$ 64,000$ million for research and development, but only $\$ 18,200$ million of that goes to civilian science and technology. Asked to explain how such a split will aid economic competitiveness, Graham replied that defence

must receive the lion's share because it requires so much more hardware. Much of this hardware is the fleet of launch vehicles planned for carrying prototype equipment for the Strategic Defense Initiative (SDI) and other military payloads.

George Brown (Democrat, California) pressed Graham to reconcile the administration's commitment to civilian space technology with the president's refusal to fund advanced space telecommunications. Graham reiterated the administration's view that government should fund "underlying" technologies and leave specific commercial applications to the private sector. The committee "does not agree with this logic", said Brown.

Committee members who were sympathetic to the administration's emphasis on space and defence displayed their own dissatisfaction with the administration's goals. As the development of SDI proceeds, they asked, will its technologies provide an infrastructure for other, nonmilitary applications? And what will be the purpose of the much-vaunted space station, other than as a floating laboratory for experiments in strategic defence? Graham admitted that the administration could do a better job articulating its policy, but declined to do so.

The committee will submit written questions to Graham, which will give him time to consult his advisers and perhaps provide more complete answers than he did at the hearing.

Nancy Heneson

\title{
India's ballistic missile base is torpedoed by local objectors
}

\section{New Delhi}

INDIA's plan to establish a thousand million dollar missile base at Baliapal on the eastern coast of Orissa state has run into trouble because some 41,000 residents have refused to be evicted. They have virtually sealed all entry points with road blocks and sign boards. No civilian or defence official, not even the chief minister of the state, has been able to set foot in the area, despite an appeal from the Prime Minister, Mr Rajiv Gandhi, saying that the facility "is of overwhelming national importance".

For logistical, technical, safety and meteorological reasons, the Defence Ministry says Baliapal is the only suitable site for the base, to be known as the National Test Range (NTR), which is expected to become operational by 1990 . It would launch ballistic missiles (now in an advanced stage of development at defence laboratories) and satellites in polar orbit and would also be used for practice firing of long-range missiles, dynamic testing of electronic warfare equipment and the launching of pilotless aircraft.

According to the Defence Ministry, the shallow sea and crescent-shaped $30-\mathrm{km}$ long coastline provide a clear firing range, and nearby hills serve as observation points, making Baliapal an ideal location. According to Dr V. S. Arunachalam, the Defence Science Adviser, the Baliapal range is vital for national security. He says that none of the other 30 sites surveyed had the advantages that Baliapal offers.

Baliapal is also said to be a safe distance away from shipping lanes, aviation routes and international boundaries. The Indian Space Research Organisation says Baliapal is more suitable for the launching of its heavy remote-sensing satellites into polar orbit than is the existing launch pad at Sriharikota, which is used for putting satellites into equatorial orbit.
US AIDS education

I $\mathrm{N}$ an apparent attempt to dispel reports of feuding between their agencies (see Nature $325,287 ; 1987)$ over how and when to teach children about AIDS (acquired immune deficiency syndrome), Surgeon General C. Everett Koop and Education Secretary William Bennett have issued a joint statement on AIDS education. In a concession to Bennett's concern about education without values, the statement says that just teaching children about "safe sex" will be "at best ineffectual" and at worst seriously harmful. The joint statement says AIDS education should stress "monogamy in marriage as a desirable and worthy thing", and that young people deserve the best scientific information about AIDS.

West Germany's election J.Nefte

LAST week's general election in West Germany brought significant changes for the individual parties, although the Christian Democratic/Liberal coalition will continue to operate. The Social Democrats comanded 37 per cent of the votes, compared with 38.2 in 1983. The Christian Democrats received 44.3 per cent of the votes, their worst result since 1949 , when the first elections took place in the federal republic.

The clear winners were the smaller parties: the liberals, who are seen as shifting the general political mood to more moderate attitudes, got 9.1 per cent of the votes and the Greens achieved the biggest gains, with 8.3 per cent. The coalition will continue, but with a weaker mandate. It is not clear whether Heinz Riesenhuber (CDU), the Minister of Research and Technology, will hold his post. There are rumours that he will go to the Defence Ministry and that Christian Democratic colleague Stavenhagen will get his post. The future of the Minister for Environment and Reactor Safety, Walter Wallmann (CDU), whose ministry was created after the catastrophe at Chernobyl, is said to be in doubt.

The Defence Ministry had originally intended to acquire 130 villages in the Baliapal/Bograi area, spread over $400 \mathrm{~km}^{2}$. Following popular protest, it has reduced its demand to $102 \mathrm{~km}^{2}$ covering 54 villages which contribute more than $\$ 50$ million a year to the state's economy from a rich harvest of rice, fish, coconut, groundnut, cashew and betel leaves. The proposed military project would devour 50,000 acres of fertile land producing 30,000 tonnes of rice as well as 30,000 betel vines. About 1,500 fishermen and their families would be left without a livelihood.

The central government is showing great restraint in the face of a concerted campaign from the local population. It is aware that a forcible takeover of the villages might lead to bloodshed and a setback for the ruling party. K.S. Jayarman 